\title{
Pulse wave velocity and its gender-related associations with cardiovascular risk factors in a high cardiovascular risk population
}

Galina Zemtsovskaja ${ }^{1,2}$, Jelena Abina ${ }^{1}$, Kalju Meigas ${ }^{1}$, Kristjan Pilt ${ }^{1}$, Margus Viigimaa ${ }^{1,2}$

${ }^{1}$ Department of Health Technologies, Tallinn University of Technology, Tallinn, Estonia ${ }^{2}$ Centre of Cardiology, North Estonia Medical Centre, Tallinn, Estonia

Submitted: 14 January 2018

Accepted: 18 June 2018

Arch Med Sci Atheroscler Dis 2018; 3: e99-e105 DOI: https://doi.org/10.5114/amsad.2018.76919 Copyright $\odot 2018$ Termedia \& Banach

\section{Abstract}

Introduction: Associations found between pulse wave velocity (PWV) and cardiovascular risk factors (CVrF) are diverse. We aimed to evaluate whether differences in PWV and its associations with CVrF in a high cardiovascular risk population exist between genders and between the whole population (WHgr) and groups of apparently healthy (AHgr) and those of hypertensive, obese or diabetics (Rgr).

Material and methods: Pulse wave velocity measured by Arteriograph was investigated in 805 adults aged 20-65, randomly selected from the Tallinn Population Register.

Results: Pulse wave velocity was the highest in Rgr and no differences were found between genders of the same group. In women of WHgr and AHgr age and SBP with addition of BMI and apolipoprotein B (ApoB) were associated with $54 \%$ and $48 \%$, and without ApoB in Rgr with only $30 \%$ of PWV values. In men aged $\geq 50$ of WHgr with elevated SBP odds ratios for increased PWV were 25.3 and 3.5, in Rgr 21.2 and 2.2, in those aged $\geq 50$ AHgr 28.4. In women aged $\geq 50$ of WHgr with elevated SBP and diabetes odds ratios were 5.5, 4.9 and 4.0, in Rgr with elevated SBP and diabetes 3.6 and 3.7, in those aged $\geq 50$ AHgr 29.3 .

Conclusions: The associations of ApoB and BMI with PWV and diabetes with elevated PWV indicative of increased aortic stiffness were unique for women. Aging and SBP were related to PWV even in AHgr, although age $\geq 50$ years in Rgr women and normal SBP in AHgr were not associated with elevated PWV.

Key words: pulse wave velocity, cardiovascular risk factors, association, Arteriograph, Tallinn population.

\section{Introduction}

According to the data on mortality rates of cardiovascular disease (CVD) of the European Guideline on cardiovascular disease prevention in clinical practice, Estonia belongs to the high-risk countries [1]. The high prevalence of cardiovascular disease risk factors and hypertension in the adult population of Tallinn, the capital of Estonia, was also demonstrated in recently published studies [2, 3].

Cardiovascular (CV) risk is a result of many interacting risk factors [1]. The term ' $\mathrm{CV}$ risk factors' refers to the significance of these factors for the prevention of cardiovascular morbidity and mortality. Conventional

\author{
Corresponding author: \\ Galina Zemtsovskaja \\ North Estonia \\ Medical Centre \\ 19 Sytiste St \\ 13419 Tallinn, Estonia \\ Phone: +37253474503 \\ E-mail: galina.zemtsovskaja@ \\ regionaalhaigla.ee
}


risk factors such as age and family history of early heart disease and modifiable risk factors, such as high blood pressure, cigarette smoking, high blood total or low-density lipoprotein cholesterol, diabetes mellitus, and obesity, are among widely known $\mathrm{CV}$ risk factors. In addition, novel or non-traditional risk factors, such as C-reactive protein, lipoprotein (a), homocysteine, apolipoproteins, and some other biochemical markers and clinical conditions, have been identified as CV risk factors [4].

In recent decades, pulse wave velocity (PWV) as a measure of arterial stiffness has been increasingly used for CV risk assessment. It has been shown to enable prediction of the CVD morbidity and mortality [5-7].

Several studies have associated arterial stiffness and PWV, its measure, with such CV risk factors as hyperlipidemia, hyperhomocysteinemia, high level of C-reactive protein, obesity, metabolic syndrome, and diabetes [8-13]. However, only a few studies have demonstrated the ability of CV risk factors other than age and blood pressure to explain the variations of PWV values, which was also confirmed by a systematic evaluative review of factors associated with PWV [14]. The discrepancies of published results are not surprising because the $\mathrm{CV}$ risk characteristics of the investigated populations were highly heterogeneous.

The purpose of our study was to investigate PWV and CV risk factors in a high-risk population of Tallinn adults. We also aimed to evaluate whether differences in the distribution of PWV and its associations with CV risk factors exist between genders and between the whole population (WHgr) and groups of apparently healthy (AHgr) and those of hypertensive, obese or diabetics (Rgr). We analyzed associations both between numerical continuous data of PWV and CV risk factors, and between their dichotomous values, classified by levels indicative of CV risk.

\section{Material and methods}

\section{Subjects}

The current investigation is a part of the cross-sectional population-based study of CV risk factors in Tallinn adults, Estonia, carried out in 2007-2009. The representative sample of population aged 20-65 was randomly selected from the Estonian Population Register, based on predefined age decades and sex, 200 subjects from each group. The sample size was determined according to the WHO protocol of the Countrywide Integrated Non-communicable Disease Intervention (CINDI) Programme (CINDI Protocol and Guidelines. Copenhagen: WHO Regional Office for Europe, 1996). The response rate was $55 \%$ for men and $64 \%$ for women, which accounted for
1184 responders. The data collected were analyzed in three directions. One study analyzed the prevalence of CVD risk factors (except PWV) in the investigated population, composed of 1111 participants with corresponding complete data [2, 3]. The other study was focused on the correlation of oxLDL and cholesterol of LDL particles, based on a smaller sample population due to the absence of specially pre-treated blood samples for part of the responders [15]. The present study with the focus on PWV consisted of 805 participants for whom data on acceptable PWV measurements were available.

The study was performed in accordance with the Helsinki Declaration of 1983 and approved by the Tallinn Medical Research Ethics Committee of the National Institute for Health Development of Estonia (No. 1005).

\section{Collection of data on cardiovascular risk factors}

An experienced and specially trained physician interviewed the participants by a structured questionnaire about basic data, including age, sex, smoking history, and past medical history. The most important facts from the medical history were the presence of hypertension, diabetes, heart disease, and current medication usage, especially against high blood pressure, diabetes and elevated lipids. The levels of blood pressure and lipids were assessed, as taken on the day of investigation, without any consideration of medication usage.

At the same visit, the physician also measured weight, height and body mass index (BMI). Body mass index was calculated as the weight in kilograms divided by the height in meters squared $\left[\mathrm{BMI}=\right.$ weight $(\mathrm{kg}) /$ height $\left.\left(\mathrm{m}^{2}\right)\right]$. After a 5-minute rest, the blood pressure was measured by a mercury sphygmomanometer two times on the right arm. Diastolic blood pressure was recorded by the Korotkoff fifth phase. The mean of two blood pressure readings was used for the analysis.

Venous blood samples were obtained in the participants in a sitting position after an overnight fast between 8.00 and 11.00 a.m. Blood was collected from the cubital vein using the standard method with Vacutainer tubes (BD Vacutainer, Belliver Industrial Estate, Plymouth; Becton, Dickinson and Co., UK). Biochemical CV risk markers were measured by reagents obtained from Roche (Roche Diagnostics, Mannheim) within $4 \mathrm{~h}$ of blood sampling on the day of collection at the Laboratory of Clinical Chemistry, North Estonian Medical Centre.

An experienced and specially trained physician performed PWV measurements by Arteriograph (TensioMed Ltd., Budapest, Hungary). Subject con- 
dition was standardized according to the recommendation on general user procedures for arterial stiffness devices.

\section{Assessment criteria for investigated parameters indicative of cardiovascular risk}

Age of participants equal to or above 50 years was defined as the age of CV risk [1]. A subject was defined as a smoker in the case of smoking at least one cigarette every day for the last 12 months. Presence of diabetes was considered if the participant knew about a diabetes diagnosis at the time of examination. BMI of participants $\geq 30 \mathrm{~kg} / \mathrm{m}^{2}$ was defined as obesity (WHO 2015). According to the recommendation of ESC/ESH Hypertension Guidelines 2013 for office blood pressure, the subjects with systolic blood pressure (SBP) $\geq 140 \mathrm{~mm}$ $\mathrm{Hg}$ and/or diastolic blood pressure (DBP) $\geq 90 \mathrm{~mm}$ $\mathrm{Hg}$ were considered as hypertensive.

The values of biochemical markers were assumed indicative of CV risk at total cholesterol (TC) $>5.0 \mathrm{mmol} / \mathrm{l}$, triglycerides (TG) $\geq 1.7 \mathrm{mmol} / \mathrm{l}$, apoli-

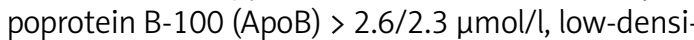
ty lipoprotein cholesterol (LDL-C) $\geq 3.0 \mathrm{mmol} / \mathrm{l}$, homocysteine $(\mathrm{Hcy}) \geq 12 \mu \mathrm{mol} / \mathrm{l}$, lipoprotein (a) $(\operatorname{Lp}(\mathrm{a}))$ $>0.3 \mathrm{~g} /$, high-sensitivity C-reactive protein (hsCRP)

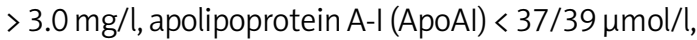
and high-density lipoprotein cholesterol (HDL-C) $<1.0 / 1.3 \mathrm{mmol} / \mathrm{l}$, with the first value appropriate for men and the second appropriate for women.

Values of PWV equal to or above $9.7 \mathrm{~m} / \mathrm{s}$ were defined as indicative of increased aortic stiffness. This categorization was based on the recommendations of the software of Arteriograph on PWV values interpreted as increased or abnormal.

\section{Statistical analysis}

Statistical analysis was performed by MedCalc statistical package version 14.8.1 (MedCalc Software, Ostend, Belgium; http://www.medcalc. org; 2014). Non-parametric statistics were applied with the presentation of all parameters as medians (with 95\% central ranges) and the assessment of differences between the independent samples by the Mann-Whitney $U$ test with two-tailed probability. $P$-values of below at least 0.05 were considered statistically significant. The correlations of PWV with CV risk factors were assessed by Spearman rank correlations analysis, and their associations by stepwise least squares multiple regression analysis. The association of increased PWV indicative of increased aortic stiffness with CV risk factors indicative of cardiovascular risk was determined by stepwise logistic regression analysis. All investigated variables were dichotomized (below versus above the level indicative of $\mathrm{CV}$ risk). The goodness of the logistic regression models was assessed by the c-statistic as well as by overall model fit through the $p$-value of $\chi^{2}$ statistics.

\section{Results}

All data of 805 participants aged 20-65 were evaluated as a group of the WHgr, and additionally in AHgr and Rgr groups. The AHgr consisted of the subjects with SBP $<140 \mathrm{~mm} \mathrm{Hg}$ and $\mathrm{DBP}<90 \mathrm{~mm} \mathrm{Hg}, \mathrm{BMI}<30 \mathrm{~kg} / \mathrm{m}^{2}$, without a history of known heart disease, diabetes, hypertension and without known medication usage against diabetes, hypertension or hyperlipidemia. Rgr consisted of the participants with at least hypertension, diabetes, or obesity; 13 of them additionally had a history of known heart disease, and 21 participants reported medication usage against hyperlipidemia.

Descriptive statistics of the groups with mean values, $95 \%$ central range, crude prevalence of their values indicative of CV risk and comparison of AHgr and Rgr are presented in Table I.

Table I shows that men and women within each group were about at the same age and with similar PWV. The prevalence of men and women at age of CV risk in WHgr was about $40 \%$, and was approximately 2.5 -fold greater in Rgr as compared with AHgr. The proportion of men and women with PWV indicative of arterial stiffening was about $20 \%$ in WHgr, and about 5 to 7 -fold greater in Rgr than in AHgr women and men, consequently.

In addition to similar age and PWV between genders of the same group, there were no significant differences in Lp(a), TC and hsCRP across all groups, and in SBP, BMI and LDL-C in Rgr.

The whole population demonstrated high prevalence of people at age of CV risk, smokers, with hypertension, obesity, and hyperlipidemia. The prevalence of smokers was about $30 \%$, and in men it was about $10 \%$ higher than in women.

The association of PWV with age, blood pressure, BMI, and biochemical CV risk factors was assessed by stepwise least squares multiple regression analysis. Only the variables that showed significant correlations with PWV in Spearman rank correlation analysis were included in the regression analysis. The final models demonstrating significant relationships are presented in Table II.

Table II demonstrates that age and SBP had a significant relationship with PWV in both genders of all groups. In women BMI and ApoB provided an additional value to the association of age and SBP with PWV, except those of Rgr women without the additional influences of $A p o B$ on this association. The models based on the above-mentioned risk factors showed the relationship of corresponding variables with about $50 \%$ of PWV values ( $R^{2}$-adjusted from 0.482 to 0.622 ), except for only $30 \%\left(R^{2}\right.$-adjusted 0.300$)$ in Rgr women. The 
Table I. Descriptive characteristics of the whole population, apparently healthy and risk groups stratified by gender

\begin{tabular}{|c|c|c|c|c|c|c|c|}
\hline \multicolumn{5}{|c|}{ Parameter Whole population $(n=805)$ Apparently healthy $(n=445)$} & \multicolumn{2}{|c|}{ Risk group $(n=360)$} & \multirow{2}{*}{$\begin{array}{c}\text { Significance of } \\
\text { difference between } \\
\text { AHgr and Rgr of the } \\
\text { same gender }(\mathrm{m} / \mathrm{w})\end{array}$} \\
\hline & $\begin{array}{c}\text { Men } \\
(n=388)\end{array}$ & $\begin{array}{l}\text { Women } \\
(n=417)\end{array}$ & $\begin{array}{c}\text { Men } \\
(n=180)\end{array}$ & $\begin{array}{l}\text { Women } \\
(n=265)\end{array}$ & $\begin{array}{c}\text { Men } \\
(n=208)\end{array}$ & $\begin{array}{l}\text { Women } \\
(n=152)\end{array}$ & \\
\hline $\begin{array}{l}\text { Age } \\
\text { [years] }\end{array}$ & $\begin{array}{c}47 \\
(24-64) \\
43 \%\end{array}$ & $\begin{array}{c}45 \\
(23-64) \\
40 \%\end{array}$ & $\begin{array}{c}39 \\
(21-62) \\
22.8 \%\end{array}$ & $\begin{array}{c}40 \\
(23-63) \\
26.0 \%\end{array}$ & $\begin{array}{c}54 \\
(33-65) \\
60.1 \%\end{array}$ & $\begin{array}{c}55 \\
(33-64) \\
65.1 \%\end{array}$ & ***/*** \\
\hline $\begin{array}{l}\mathrm{PWV} \\
{[\mathrm{m} / \mathrm{s}]}\end{array}$ & $\begin{array}{c}7.1 \\
(4.8-12.9) \\
18 \%\end{array}$ & $\begin{array}{c}6.8 \\
(4.6-12.4) \\
17 \%\end{array}$ & $\begin{array}{c}6.2 \\
(4.6-11.0) \\
4.4 \% \\
\end{array}$ & $\begin{array}{c}6.2 \\
(4.4-11.3) \\
6.8 \% \\
\end{array}$ & $\begin{array}{c}8.5 \\
(5.4-13.2) \\
29.8 \% \\
\end{array}$ & $\begin{array}{c}8.9 \\
(5.5-13.4) \\
35.5 \% \\
\end{array}$ & $* * * / * * *$ \\
\hline $\begin{array}{l}\text { SBP } \\
{[\mathrm{mm} \mathrm{Hg}]}\end{array}$ & $\begin{array}{c}129 \\
(102-193) \\
33 \%\end{array}$ & $\begin{array}{c}120^{* * *} \\
(94-173) \\
21 \%\end{array}$ & $\begin{array}{c}119 \\
(98-137) \\
\text { No }\end{array}$ & $\begin{array}{c}112^{* \star \star} \\
(92-137) \\
\text { No }\end{array}$ & $\begin{array}{c}145 \\
(115-206) \\
62.0 \%\end{array}$ & $\begin{array}{c}144 \\
(109-187) \\
57.9 \%\end{array}$ & $* * * / * * *$ \\
\hline $\begin{array}{l}\text { DBP } \\
{[\mathrm{mm} \mathrm{Hg}]}\end{array}$ & $\begin{array}{c}84 \\
(62-114) \\
35 \%\end{array}$ & $\begin{array}{c}75^{\star \star \star} \\
(56-104) \\
18 \%\end{array}$ & $\begin{array}{c}77 \\
(57-88) \\
\text { No }\end{array}$ & $\begin{array}{c}71^{\star \star \star} \\
(54-86) \\
\text { No }\end{array}$ & $\begin{array}{c}93 \\
(74-122) \\
65.9 \%\end{array}$ & $\begin{array}{c}90^{\star * \star} \\
(63-116) \\
49.3 \%\end{array}$ & $* * * / * * *$ \\
\hline $\begin{array}{l}\mathrm{BMI} \\
{\left[\mathrm{kg} / \mathrm{m}^{2}\right]}\end{array}$ & $\begin{array}{c}27 \\
(20-37) \\
25 \%\end{array}$ & $\begin{array}{c}24^{* * *} \\
(18-38) \\
19 \%\end{array}$ & $\begin{array}{c}25 \\
(20-29) \\
\text { No }\end{array}$ & $\begin{array}{c}23^{* * *} \\
(18-30) \\
\text { No }\end{array}$ & $\begin{array}{c}29 \\
(22-40) \\
46.6 \%\end{array}$ & $\begin{array}{c}30 \\
(19-43) \\
52.6 \%\end{array}$ & $* * * / * * *$ \\
\hline $\begin{array}{l}\text { TC } \\
{[\mathrm{mmol} / \mathrm{l}]}\end{array}$ & $\begin{array}{c}5.5 \\
(3.5-8.1) \\
69 \%\end{array}$ & $\begin{array}{c}5.3^{\star \star} \\
(3.7-7.8) \\
62 \%\end{array}$ & $\begin{array}{c}5.3 \\
(3.2-6.9) \\
62.2 \%\end{array}$ & $\begin{array}{c}5.1 \\
(3.7-7.5) \\
53.6 \%\end{array}$ & $\begin{array}{c}5.7 \\
(3.8-8.3) \\
75.5 \%\end{array}$ & $\begin{array}{c}5.7 \\
(3.7-8.1) \\
75.7 \%\end{array}$ & $* * * / * * *$ \\
\hline $\begin{array}{l}\text { TG } \\
{[\mathrm{mmol} / \mathrm{l}]}\end{array}$ & $\begin{array}{c}1.3 \\
(0.5-4.9) \\
34 \% \\
\end{array}$ & $\begin{array}{c}1.0^{\star \star \star} \\
(0.5-2.6) \\
18 \% \\
\end{array}$ & $\begin{array}{c}1.1 \\
(0.5-3.5) \\
20.6 \% \\
\end{array}$ & $\begin{array}{c}0.9^{\star * *} \\
(0.5-2.1) \\
10.9 \%\end{array}$ & $\begin{array}{c}1.5 \\
(0.6-5.6) \\
44.7 \% \\
\end{array}$ & $\begin{array}{c}1.3^{\star \star} \\
(0.5-2.9) \\
31.6 \% \\
\end{array}$ & $* * * / * * *$ \\
\hline $\begin{array}{l}\text { ApoAl } \\
{[\mu \mathrm{mol} / \mathrm{l}]}\end{array}$ & $\begin{array}{c}54.6 \\
(39.9-73.9) \\
\text { No }\end{array}$ & $\begin{array}{c}63.7^{\mathrm{a}} \\
(48.1-86.0) \\
\text { No }\end{array}$ & $\begin{array}{c}54.2 \\
(41.4-73.5) \\
\text { No }\end{array}$ & $\begin{array}{c}65.0^{\mathrm{a}} \\
(48.2-86.3) \\
\text { No } \\
\end{array}$ & $\begin{array}{c}55.0 \\
(39.7-74.3) \\
\text { No } \\
\end{array}$ & $\begin{array}{c}62.1^{\mathrm{a}} \\
(45.3-85.8) \\
\text { No }\end{array}$ & $0.962 /^{*}$ \\
\hline $\begin{array}{l}\text { ApoB } \\
{[\mu \mathrm{mol} / \mathrm{l}]}\end{array}$ & $\begin{array}{c}3.4 \\
(1.8-5.5) \\
81 \%\end{array}$ & $\begin{array}{c}3.1^{\mathrm{a}} \\
(1.8-4.9) \\
83 \%\end{array}$ & $\begin{array}{c}3.2 \\
(1.6-4.7) \\
73.3 \%\end{array}$ & $\begin{array}{c}2.9^{\mathrm{a}} \\
(1.8-4.7) \\
78.9 \%\end{array}$ & $\begin{array}{c}3.8 \\
(2.2-5.8) \\
87.5 \%\end{array}$ & $\begin{array}{c}3.5^{\mathrm{a}} \\
(2.0-5.3) \\
91.4 \%\end{array}$ & ***/*** \\
\hline $\begin{array}{l}\mathrm{HDL}-\mathrm{C} \\
{[\mathrm{mmol} / \mathrm{l}]}\end{array}$ & $\begin{array}{c}1.3 \\
(0.8-2.3) \\
9 \% \\
\end{array}$ & $\begin{array}{c}1.7^{a} \\
(1.1-2.6) \\
12 \% \\
\end{array}$ & $\begin{array}{c}1.4 \\
(0.9-2.3) \\
6.1 \% \\
\end{array}$ & $\begin{array}{c}1.8^{\mathrm{a}} \\
(1.1-2.7) \\
7.5 \% \\
\end{array}$ & $\begin{array}{c}1.3 \\
(0.8-2.1) \\
11.1 \% \\
\end{array}$ & $\begin{array}{c}1.6^{\mathrm{a}} \\
(0.9-2.5) \\
19.1 \% \\
\end{array}$ & $* * / * * *$ \\
\hline $\begin{array}{l}\text { LDL-C } \\
{[\mathrm{mmol} / \mathrm{l}]}\end{array}$ & $\begin{array}{c}3.7 \\
(1.9-5.8) \\
93 \%\end{array}$ & $\begin{array}{c}3.3^{\star \star *} \\
(1.8-5.5) \\
82 \%\end{array}$ & $\begin{array}{c}3.5 \\
(1.7-5.1) \\
89.4 \%\end{array}$ & $\begin{array}{c}3.1^{\star * *} \\
(1.7-5.3) \\
78.1 \%\end{array}$ & $\begin{array}{c}4.0 \\
(2.1-6.2) \\
95.2 \%\end{array}$ & $\begin{array}{c}3.7 \\
(1.9-5.7) \\
88.8 \%\end{array}$ & $* * * / * * *$ \\
\hline $\begin{array}{l}\text { Hcy } \\
{[\mu \mathrm{mol} / \mathrm{l}]}\end{array}$ & $\begin{array}{c}13 \\
(8.9-25.9) \\
69 \% \\
\end{array}$ & $\begin{array}{c}11.6^{\star \star \star} \\
(6.6-20.2) \\
45 \%\end{array}$ & $\begin{array}{c}13 \\
(9-22) \\
62.8 \%\end{array}$ & $\begin{array}{l}11^{\star \star \star} \\
(7-20) \\
39.6 \%\end{array}$ & $\begin{array}{c}14 \\
(9-28) \\
75 \%\end{array}$ & $\begin{array}{l}12^{* \star *} \\
(7-24) \\
55.3 \%\end{array}$ & $* * * / * *$ \\
\hline $\begin{array}{l}\operatorname{Lp}(\mathrm{a}) \\
{[\mathrm{g} / \mathrm{l}]}\end{array}$ & $\begin{array}{c}0.1 \\
(0.1-1.3) \\
26 \%\end{array}$ & $\begin{array}{c}0.1 \\
(0.1-1.2) \\
26 \%\end{array}$ & $\begin{array}{c}0.1 \\
(0.1-1.2) \\
23.9 \%\end{array}$ & $\begin{array}{c}0.1 \\
(0.1-1.3) \\
23.4 \%\end{array}$ & $\begin{array}{c}0.12 \\
(0.08-1.40) \\
28.4 \%\end{array}$ & $\begin{array}{c}0.14 \\
(0.08-1.21) \\
29.6 \%\end{array}$ & $\begin{array}{l}0.675 / \\
0.191\end{array}$ \\
\hline $\begin{array}{l}\text { hsCRP } \\
{[\mathrm{mg} / \mathrm{ll}]}\end{array}$ & $\begin{array}{c}1.3 \\
(0.2-9.7) \\
19 \%\end{array}$ & $\begin{array}{c}1.1^{*} \\
(0.2-9.8) \\
16 \%\end{array}$ & $\begin{array}{c}0.9 \\
(0.2-6.5) \\
12.2 \%\end{array}$ & $\begin{array}{c}0.8 \\
(0.2-7.8) \\
8.7 \%\end{array}$ & $\begin{array}{c}1.6 \\
(0.3-12.8) \\
24.5 \%\end{array}$ & $\begin{array}{c}1.7 \\
(0.4-12.3) \\
28.9 \%\end{array}$ & ***/*** \\
\hline Diabetes & $5 \%$ & $3 \%$ & No & No & $10.1 \%$ & $8.6 \%$ & \\
\hline Smokers & $35 \%$ & $24 \%$ & $39.4 \%$ & $19.2 \%$ & $30.8 \%$ & $31.6 \%$ & \\
\hline
\end{tabular}

Values are medians (95\% central range) and crude prevalence. ${ }^{*} p<0.05,{ }^{* *} p<0.01,{ }^{* *} p<0.001$, and an exact number in case of nonsignificant difference, for the differences between genders within groups and between groups of the same gender. In comparison between genders, it means higher in men than in women. ${ }^{a}$ The differences between genders were not assessed for ApoAl, ApoB and HDL-C due to gender-specific differences in the reference values. In the comparison between the same gender groups, it means higher in Rgr than in AHgr, except for HDL-C and apoAl, which means higher in AHgr than in Rgr.

multiple correlation coefficients indicated that the above-mentioned variables were in a close relationship with PWV, except for Rgr women with worse results.
In addition, the association of PWV indicative of increased arterial stiffness with age, blood pressure, $\mathrm{BMI}$ and the level of biochemical CV risk factors indicative of CV risk as well as with diabetes and smoking 
Table II. Final models of the association between pulse wave velocity and cardiovascular risk factors across groups stratified by gender

\begin{tabular}{|c|c|c|c|c|c|}
\hline Groups & Variables & Coefficient $r_{\text {partial }}$ & $P$-value & $\begin{array}{c}\text { Multiple correla- } \\
\text { tion coefficient }\end{array}$ & $R^{2}$-adjusted \\
\hline \multirow{2}{*}{$\begin{array}{l}\text { Whole population } \\
\text { men }(n=388)\end{array}$} & Age & 0.629 & $<0.0001$ & \multirow[t]{2}{*}{0.790} & \multirow[t]{2}{*}{0.622} \\
\hline & SBP & 0.433 & $<0.0001$ & & \\
\hline \multirow{4}{*}{$\begin{array}{l}\text { Whole population } \\
\text { women }(n=417)\end{array}$} & Age & 0.413 & $<0.0001$ & \multirow[t]{4}{*}{0.739} & \multirow[t]{4}{*}{0.541} \\
\hline & SBP & 0.454 & $<0.0001$ & & \\
\hline & BMI & -0.129 & $<0.01$ & & \\
\hline & ApoB & 0.113 & $<0.05$ & & \\
\hline \multirow{2}{*}{$\begin{array}{l}\text { Apparently healthy } \\
\text { men }(n=180)\end{array}$} & Age & 0.647 & $<0.0001$ & \multirow[t]{2}{*}{0.679} & \multirow[t]{2}{*}{0.455} \\
\hline & SBP & 0.165 & $<0.05$ & & \\
\hline \multirow{4}{*}{$\begin{array}{l}\text { Apparently healthy } \\
\text { women }(n=265)\end{array}$} & Age & 0.471 & $<0.0001$ & \multirow[t]{4}{*}{0.700} & \multirow[t]{4}{*}{0.482} \\
\hline & SBP & 0.390 & $<0.0001$ & & \\
\hline & $\mathrm{BMI}$ & -0.176 & $<0.01$ & & \\
\hline & ApoB & 0.130 & $<0.05$ & & \\
\hline \multirow{2}{*}{$\begin{array}{l}\text { Risk group men } \\
(n=208)\end{array}$} & Age & 0.620 & $<0.0001$ & \multirow[t]{2}{*}{0.727} & \multirow[t]{2}{*}{0.524} \\
\hline & SBP & 0.341 & $<0.0001$ & & \\
\hline \multirow{3}{*}{$\begin{array}{l}\text { Risk group women } \\
(n=152)\end{array}$} & Age & 0.341 & $<0.0001$ & \multirow[t]{3}{*}{0.560} & \multirow[t]{3}{*}{0.300} \\
\hline & SBP & 0.317 & $<0.0001$ & & \\
\hline & BMI & -0.179 & $<0.05$ & & \\
\hline
\end{tabular}

Coefficient $p_{\text {artial }}$ is a measure of the relative strength of the association independent of the units of measurement; $R^{2}$-adjusted is a coefficient of determination adjusted for the number of independent variables. In the regression model for men of the whole group, the following variables were studied in addition to modifying the final model: apoAl, apoB, BMI, hSCRP, DBP, diabetes, Hcy, LDL-C, LP (a), TC and TG; for women - hsCRP, DBP, diabetes, Hcy, TC and TG; for the apparently healthy men - apoB, hsCRP, DBP, LDL-C and TC; for womenapoAl, hsCRP, DBP, Hcy, HDL-C, TC and TG; for risk group men - apoAl, DBP, Hcy, and Lp(a); for women - DBP, Hcy and TC.

was evaluated. Table III presents the final models containing CV risk factors in significant association.

Table III demonstrates the overall good model fit by $\chi^{2}$ statistics and the near perfect discriminatory power shown by the concordance index (c-statistic) value of 1.0, with slightly worse values in Rgr women.

All men and women without hypertension, diabetes or obesity aged equal to or above 50 had high OR for increased PWV, and thus increased arterial stiffness. In addition, men with increased SBP had higher odds for increased PWV. Similar to men, women with increased SBP also had higher odds, even independent of their age, but only at additional influences of diabetes.

\section{Discussion}

This article is the first to present data on PWV distribution and its association with CV risk factors in a population of Tallinn adults, Estonia. To the best of our knowledge, the present study is the first to demonstrate separately the differences in the gender-related associations between PWV measured by Arteriograph and CV risk factors in a high-risk population aged 20-65 stratified by absence or presence of hypertension, diabetes or obesity.

Tallinn adults had mostly high prevalence of CV risk factors, especially hyperlipidemia with the crude prevalence of increased level of main lipids from $60 \%$ to $90 \%$. About $30 \%$ were smokers. However, $46 \%$ of men and $65 \%$ of women had normal blood pressure and were not obese or diabetics. That was the reason why we separated out their data into a separate AHgr, and the rest formed the Rgr.

The highest prevalence of increased PWV and most of the CV risk factors were found in Rgr adults who were also older. The reason is probably the highest age as well as prevalence of CV risk factors. The study of Boutouyrie et al. [16] also demonstrated a more prominent increase of PWV with age in subjects with high blood pressure, and a more significant increase of blood pressure in older subjects. Our finding is in accordance with their results in terms of the highest blood pressure in Rgr with the highest age, and the highest PWV in this group. 
Table III. Final models showing associations between pulse wave velocity indicative of increased arterial stiffness and the level of cardiovascular risk factors indicative of cardiovascular risk across groups stratified by gender

\begin{tabular}{|c|c|c|c|c|c|c|}
\hline Groups & Variables & $\begin{array}{l}\text { Odds } \\
\text { ratio }\end{array}$ & $\begin{array}{l}95 \% \mathrm{Cl} \text { of } \\
\text { odds ratio }\end{array}$ & $\begin{array}{l}\text { Overall model } \\
\text { fit ( } p \text {-value of } \\
\chi^{2} \text { statistics) }\end{array}$ & c-statistic & $\begin{array}{l}95 \% \mathrm{Cl} \text { of } \\
\text { c-statistic }\end{array}$ \\
\hline \multirow{2}{*}{$\begin{array}{l}\text { Whole population } \\
\text { men }(n=388)\end{array}$} & Age $\geq 50$ years & 25.3 & $8.8-72.3$ & \multirow[t]{2}{*}{$<0.0001$} & \multirow[t]{2}{*}{0.864} & \multirow[t]{2}{*}{$0.826-0.896$} \\
\hline & $\mathrm{SBP} \geq 140 \mathrm{~mm} \mathrm{Hg}$ & 3.5 & $1.9-6.6$ & & & \\
\hline \multirow{3}{*}{$\begin{array}{l}\text { Whole population } \\
\text { women }(n=417)\end{array}$} & Age $\geq 50$ years & 5.5 & $2.8-10.7$ & \multirow[t]{3}{*}{$<0.0001$} & \multirow[t]{3}{*}{0.817} & \multirow[t]{3}{*}{$0.777-0.853$} \\
\hline & $\mathrm{SBP} \geq 140 \mathrm{~mm} \mathrm{Hg}$ & 4.9 & $2.7-9.0$ & & & \\
\hline & Diabetes & 4.0 & $1.2-13.5$ & & & \\
\hline $\begin{array}{l}\text { Apparently healthy } \\
\text { men }(n=180)\end{array}$ & Age $\geq 50$ years & 28.4 & $3.4-239$ & $<0.0001$ & 0.839 & $0.777-0.889$ \\
\hline $\begin{array}{l}\text { Apparently healthy } \\
\text { women }(n=265)\end{array}$ & Age $\geq 50$ years & 29.3 & $6.5-131$ & $<0.0001$ & 0.837 & $0.787-0.880$ \\
\hline \multirow{2}{*}{$\begin{array}{l}\text { Risk group men } \\
(n=208)\end{array}$} & Age $\geq 50$ years & 21.2 & $6.3-71.1$ & \multirow[t]{2}{*}{$<0.0001$} & \multirow[t]{2}{*}{0.787} & \multirow[t]{2}{*}{$0.725-0.840$} \\
\hline & $\mathrm{SBP} \geq 140 \mathrm{~mm} \mathrm{Hg}$ & 2.2 & $1.0-4.8$ & & & \\
\hline \multirow{2}{*}{$\begin{array}{l}\text { Risk group women } \\
(n=152)\end{array}$} & Diabetes & 3.7 & $1.1-12.7$ & \multirow[t]{2}{*}{$<0.01$} & \multirow[t]{2}{*}{0.660} & \multirow[t]{2}{*}{$0.579-0.735$} \\
\hline & $\mathrm{SBP} \geq 140 \mathrm{~mm} \mathrm{Hg}$ & 3.6 & $1.6-7.7$ & & & \\
\hline
\end{tabular}

The PWV within groups was found without significant heterogeneity between genders. Considering the higher level of most CV risk factors in men of each group than in women, while age was about the same, it seems that age had a major influence on the similarity in PWV. Some authors [17-19] have also reported absence of differences in PWV between genders, and the results of some studies with higher PWV in women than in men can probably be explained by the higher average age of women in those studies [20].

We evaluated statistically the association between PWV and CV risk factors and also the association between increased PWV and the level of $\mathrm{CV}$ risk factors indicative of $\mathrm{CV}$ risk across genders and groups.

It was demonstrated that men of WHgr, AHgr and Rgr had the relationship of age and SBP with $62 \%, 46 \%$ and $52 \%$ of PWV values. However, in women some discrepancies between groups and genders were obtained. In contrast to men, in women $\mathrm{BMI}$ and $\mathrm{ApoB}$ explained part of the variation in PWV in addition to age and SBP. While $B M I$ was related to PWV in all women, apoB showed a relationship only in $\mathrm{WHgr}$ and $\mathrm{AHgr}$. The resulting models in women showed a relationship with $54 \%$ of PWV in WHgr, $48 \%$ in AHgr, and only $30 \%$ in Rgr. Our results are very similar to other studies that have indicated that only about half of the variability could be explained by $\mathrm{CV}$ risk factors, mainly by age and SBP $[20,21]$. Some other factors might contribute to the variance of PWV values, such as genetics, as demonstrated in a study of twin pairs with the power of 45-58\% [22].

The relationship of BMI with PWV in women of our study was reversible, which is in accordance with the evidence of several systematic reviews of the 'obesity paradox' that obesity seems to be protective in patients with CVD [1].

Aging showed not only a strong relationship with PWV, but also the strongest association at CV risk levels with increased PWV, indicative of increased arterial stiffness. Age equal to or higher than 50 years was the only variable with a close association and high OR in AHgr, independent of gender. Men of remaining groups at $C V$ risk age also had high OR, and with elevated SBP had additional OR. However, discrepancies in variables and OR were obtained in women of the remaining groups. While SBP and diabetes were unique variables for both groups, age had a significant OR only in the whole group. In contrast to men of Rgr, women with diabetes had higher odds for increased PWV than those without diabetes.

The observed differences between genders may be explained by the fluctuations of female hormones, which may provoke discrepancies in the influence of CV risk factors on PWV both between different hormonal periods in women and in the comparison of women with men [23].

Previous studies have observed mostly the association of only age and SBP with PWV. Even when evidence of some associations was given, no significant contribution of other $\mathrm{CV}$ risk factors to PWV were recorded [5, 14, 16, 17, 24, 25].

Although gender studies have been reported, no separate investigations of gender-related features of the association of CV risk factors with PWV measured by Arteriograph are available. Nor has, to the best of our knowledge, an association of diabetes with increased PWV or a relationship of BMI with PWV variations been demonstrated 
before separately in women aged 20-65, and the last variable even in women without obesity.

Among our findings is the strong relationship between ApoB and PWV in AHgr women. As compared with other biochemical CV risk factors, the relation of $A p o B$ to PWV has been investigated only to some extent. In this regard, Amar et al. found a close relationship between $A p o B$ and PWV, which is interesting although they observed a group with risk factors that is not closely comparable with our AHgr [26].

In conclusion, the discrepancies obtained between genders and groups indicate more precisely the groups and risk factors for the preventive strategy in a high-risk population. Thus, hypertensive men aged equal to or above 50 years as well as hypertensive women with diabetes, and also the increase of apolipoprotein B level in apparently healthy women, require special attention to avoid the development of increased arterial stiffness timely.

\section{Acknowledgments}

This investigation was funded by the Estonian Ministry of Education and Research under institutional research financing IUT 19-2. The funders had no role in the manuscript preparation process.

\section{Conflict of interest}

The authors declare no conflict of interest.

\section{References}

1. Massimo F, Piepoli AW, Hoes SA, et al. European Guideline on cardiovascular disease prevention in clinical practice. Eur Heart J 2016; 37: 2315-81.

2. Kaldmäe M, Zemtsovskaja G, Abina J, Viigimaa M. Prevalence of cardiovascular disease risk factors in Tallinn, Estonia. Medicina 2017; 53: 268-76.

3. Kaldmäe M, Viigimaa M, Zemtsovskaja G, Kaart T, Abina J, Annuk M. Prevalence and determinants of hypertension in Estonian adults. Scand J Public Health 2014; 42: 504-10.

4. Mozaffarian D, Wilson PW, Kannel WB. Beyong established and novel risk factors: lifestyle risk factors for cardiovascular disease. Circulation 2008; 117: 3031-8.

5. Laurent S, Cockcroft J, Van Bortel L, et al. Expert consensus document on arterial stiffness: methodological issues and clinical applications. Eur Heart J 2006; 27: 2588-605.

6. Vlachopoulos C, Aznaouridis K, Stefanadis C. Prediction of cardiovascular events and all-cause mortality with arterial stiffness. J Am Coll Cardiol 2010; 55: 1318-27.

7. Safar ME, Henry O, Meaume S. Aortic pulse wave velocity: an independent marker of cardiovascular risk. Am J Geriatr Cardiol 2002; 11: 295-8.

8. McEniery CM, Yasmin KM, Kaisa M, et al. The impact of cardiovascular risk factors on aortic stiffness and wave reflections depends on age. The Anglo-Cardiff Collaborative Trial (ACCT III). Hypertension 2010; 56: 591-7.

9. Wang XN, Ye P, Cao RH, et al. Plasma homocysteine is a predictive factor for arterial stiffness: a community- based 4.8-year prospective study. J Clin Hypertens 2015; 17: 594-600.

10. Yasmin, Eniery CM, Wallace $S$, et al. C-reactive protein is associated with arterial stiffness in apparently healthy individuals. Arterioscler Thromb Vasc Biol 2004; 24: 969-74.

11. Ferreira I, Henry RM, Twisk JW, et al. Amsterdam Growth, Health Longitudinal Study. The metabolic syndrome, cardiopulmonary fitness, and subcutaneous trunk fat as independent determinants of arterial stiffness: the Amsterdam Growth and Health Longitudinal Study. Arch Intern Med 2005; 165: 875-82.

12. Schram MT, Henry RM, van Dijk RA, et al. Increased central artery stiffness in impaired glucose metabolism and type 2 diabetes: The Hoorn Study. Hypertension 2004; 43: 176-81.

13. Safar ME, Czernichow S, Blacher J. Obesity, arterial stiffness, and cardiovascular risk. J Am Soc Nephrol 2006; 17: S109-11.

14. Cecelja M, Chowienczyk. Dissociation of aortic pulse wave velocity with risk factors for cardiovascular disease other than hypertension. Hypertension 2009; 54: 1328-36.

15. Viigimaa M, Abina J, Zemtsovskaya G, et al. Malondialdehyde-modified low-density lipoproteins as biomarker for atherosclerosis. Blood Press 2010; 19: 164-8.

16. Boutouyrie P, Vermeersch SJ. Determinants of pulse wave velocity in healthy people and in the presence of cardiovascular risk factors: "establishing normal and reference values". Eur Heart J 2010; 31: 2338-50.

17. Farro I, Bia D, Zocalo Y, et al. Pulse wave velocity as marker of preclinical arterial disease: reference levels in a Uruguayan population considering wave detection algorithms, path lengths, aging, and blood pressure. Int J Hypertens 2012; 2012: 169359.

18. Hickson SS, Butlin M, Graves M, et al. The relationship of age with regional aortic stiffness and diameter. JACC Cardiovasc Imaging 2010; 3: 1247-55.

19. Vermeersch SJ, Rietzschel ER, De Buyzere ML, et al. Age and gender related patterns in carotid-femoral PWV and carotid and femoral stiffness in a large healthy, middle-aged population. J Hypertens 2008; 26: 1411-9.

20. Ring M, Eriksson MJ, Zierath JR, Caidahl K. Arterial stiffness estimation in healthy subjects: a validation of oscillometric (Arteriograph) and tonometric (Sphygmocor) techniques. Hypertens Res 2014; 37: 999-1007.

21. Mitchell GF, Parise H, Benjamin EJ, et al. Changes in arterial stiffness and wave reflection with advancing age in healthy men and women. Hypertension 2004; 43: 1239-45.

22. Tarnoki AD, Tarnoki DL, Bogl LH, Medda E, Fagnani C, Nisticò L. Association of body mass index with arterial stiffness and blood pressure components: a twin study. Atherosclerosis 2013; 229: 388-95.

23. Payne RA, Wilkinson IB, Webb DJ. Arterial stiffness and hypertension: emerging concepts. Hypertension 2010; 55: 9-14.

24. Lebrun CEI, Schouw YT, Bak AAA, et al. Arterial stiffness in postmenopausal women: determinants of pulse wave velocity. J Hypertens 2002; 20: 2165-72.

25. Kim EJ, Park JS, Suh SY, et al. Relationship between blood pressure parameters and pulse wave velocity in normotensive and hypertensive subjects: invasive study. J Hum Hypertens 2007; 21: 141-8.

26. Amar J, Ruidavets JB, Chamontin B, Drouet L, Ferrieres J. Arterial stiffness and cardiovascular risk factors in a population-based study. J Hypertens 2001; 19: 381-7. 